\begin{tabular}{lcl}
\hline Bentham OPEN & Open Medicine Journal \\
CrossMark & Content list available at: www.benthamopen.com/MEDJ/ \\
\hline
\end{tabular}

\title{
EDITORIAL
}

\section{Hepatitis $C$ and Psychiatric and Substance Use Disorders Co- morbidities; Caring for People with Hepatitis C: Lessons from the Past that Inform Expectations in the Future}

Chronic hepatitis $\mathrm{C}$ virus (HCV) infection is estimated to affect approximately $3 \%$ of the world's population and, as such, is the most common blood-borne viral infection. Approximately 170-200 million people are considered to be infected worldwide, and in the United States as many as 5 million may have chronic HCV [1 - 3]. As is well known, people with $\mathrm{HCV}$ are often asymptomatic for a decade or more after they are initially infected and thus the risk of liver fibrosis, cirrhosis, hepatocellular cancer and mortality is increased if HCV is not promptly diagnosed and treated.

Psychiatric and substance use disorders (SUD) are common co-morbid conditions found in people with HCV and are factors in predisposing people to HCV infection. The primary cause of HCV infection is intravenous drug use (IVDU) and, taken together, various studies suggest that between $60-90 \%$ of people with HCV have a past or current history of SUD [4 - 7]. Alcohol use disorders (AUDs) are also common and current harmful alcohol use among people recently diagnosed with $\mathrm{HCV}$ has been reported to be as high as 30\% [6 - 8]. Furthermore, several studies suggest that depression-related diagnoses are higher among people with HCV as compared to the general population and estimates of the incidence of clinically significant depressive symptomatology in people with HCV range between 20-40\% [6, 8 11]. These various co-morbidities are reasons that clinicians will exclude people from antiviral therapy in spite of evidence that people with HCV and co-morbid psychiatric and substance use disorders can be safely and effectively treated [12 - 22]. Furthermore the neuropsychiatric side-effects of alpha interferon, until recently the mainstay of antiviral therapy, have necessitated an appreciation and assessment of psychiatric co-morbidities (specifically depression) found in people with $\operatorname{HCV}[14,23]$.

We have learned very important lessons about HCV treatment in the last decade. Among them is an appreciation of the complex care needs of people with HCV, needs that are not limited to the liver and therefore demands a holistic care approach. The common psychiatric and substance use co-morbidities that often precede and usually accompany HCV infection are primary considerations that demand this approach and optimal treatment of HCV is provided by interdisciplinary teams of clinicians who best meet these various and multifaceted care needs [18, $24-28]$. The availability of new medications and interferon- free antiviral therapy regimens will decrease the risk of neuropsychiatric side effects and shorten the duration of treatment. This will have the consequence of dramatically altering the clinical landscape of HCV care and will increase the number of eligible treatment candidates as treatment of people with HCV and co-morbid psychiatric and substanceuse disorders will become increasingly viable [29]. While economically developed countries will rely on expensive interferon-free antiviral therapy, less developed countries will continue to use interferon-based therapies suggesting that lessons learned should not be lessons forgotten.

The proposed thematic issue will begin with articles that review the natural history and prevalence of $\mathrm{HCV}$, and the psychiatric and substance use disorders co-morbidities and neuropsychiatric side effects of antiviral therapy in people with HCV. This will be followed by articles that discuss the healthcare and economic consequences or interferon-free treatment regimens, and healthcare network strategies for disease management. The efficacy and viability of new antiviral medications, and the consequent changes in prescribing practices, treatment strategies, and new treatment options/availability with a focus on those with psychiatric and substance use comorbidities will also be reviewed. 


\section{REFERENCES}

[1] Marinho RT, Barreira DP. Hepatitis C, stigma and cure. World J Gastroenterol 2013; 19(40): 6703-9. [http://dx.doi.org/10.3748/wjg.v19.i40.6703] [PMID: 24187444]

[2] Centers for Disease Control and Prevention. Surveillance for Viral Hepatitis -United States 2014. Available from: http://www.cdc.gov/ hepatitis/Statistics/2011Surveillance/Commentary.htm\#hepC.

[3] Chak E, Talal AH, Sherman KE, Schiff ER, Saab S. Hepatitis C virus infection in USA: an estimate of true prevalence. Liver Int 2011; 31(8): $1090-101$. [http://dx.doi.org/10.1111/j.1478-3231.2011.02494.x] [PMID: 21745274]

[4] Johnson ME, Fisher DG, Fenaughty A, Theno SA, Hepatitis C. Hepatitis C virus and depression in drug users. Am J Gastroenterol 1998; 93(5): 785-9.

[http://dx.doi.org/10.1111/j.1572-0241.1998.225_a.x] [PMID: 9625128]

[5] Hagan H, Des Jarlais DC. HIV and HCV infection among injecting drug users. Mt Sinai J Med 2000; 67(5-6): 423-8. [PMID: 11064493]

[6] el-Serag HB, Kunik M, Richardson P, Rabeneck L. Psychiatric disorders among veterans with hepatitis C infection. Gastroenterology 2002; 123(2): 476-82. [http://dx.doi.org/10.1053/gast.2002.34750] [PMID: 12145801]

[7] Huckans MS, Blackwell AD, Harms TA, Hauser P. Management of hepatitis C disease among VA patients with schizophrenia and substance use disorders. Psychiatr Serv 2006; 57(3): 403-6. [http://dx.doi.org/10.1176/appi.ps.57.3.403] [PMID: 16525001]

[8] Fireman M, Indest DW, Blackwell A, Whitehead AJ, Hauser P. Addressing tri-morbidity (hepatitis C, psychiatric disorders, and substance use): the importance of routine mental health screening as a component of a comanagement model of care. Clin Infect Dis 2005; 40(Suppl. 5): S286-91. [http://dx.doi.org/10.1086/427442] [PMID: 15768336]

[9] Dwight MM, Kowdley KV, Russo JE, Ciechanowski PS, Larson AM, Katon WJ. Depression, fatigue, and functional disability in patients with chronic hepatitis C. J Psychosom Res 2000; 49(5): 311-7. [http://dx.doi.org/10.1016/S0022-3999(00)00155-0] [PMID: 11164055]

[10] Golden J, O’Dwyer AM, Conroy RM. Depression and anxiety in patients with hepatitis C: prevalence, detection rates and risk factors. Gen Hosp Psychiatry 2005; 27(6): 431-8. [http://dx.doi.org/10.1016/j.genhosppsych.2005.06.006] [PMID: 16271658]

[11] Nelligan J, Loftis JM, Matthews AM, Zucker Z, Linke A, Hauser P. Depression co-morbidity and antidepressant use in veterans with chronic hepatitis C. J Clin Psychiatry 2008; 69(5): 810-6. [http://dx.doi.org/10.4088/JCP.v69n0514] [PMID: 18426262]

[12] Edlin BR, Seal KH, Lorvick J, et al. Is it justifiable to withhold treatment for hepatitis C from illicit-drug users? N Engl J Med 2001; 345(3): 211-5.

[http://dx.doi.org/10.1056/NEJM200107193450311] [PMID: 11463019]

[13] Dalgard O, BjA,ro K, Hellum K, et al. Treatment of chronic hepatitis C in injecting drug users: 5 year's follow-up. Eur Addict Res 2002; 8(1): 45-9. [http://dx.doi.org/10.1159/000049487] [PMID: 11818693]

[14] Hauser P, Khosla J, Aurora H, et al. A prospective study of the incidence and open-label treatment of interferon-induced major depressive disorder in patients with hepatitis C. Mol Psychiatry 2002; 7(9): 942-7. [http://dx.doi.org/10.1038/sj.mp.4001119] [PMID: 12399946]

[15] Bini EJ, Bräu N, Currie S, et al. Prospective multicenter study of eligibility for antiviral therapy among 4,084 U.S. veterans with chronic hepatitis C virus infection. Am J Gastroenterol 2005; 100(8): 1772-9.

[http://dx.doi.org/10.1111/j.1572-0241.2005.41860.x] [PMID: 16086714]

[16] Chainuvati S, Khalid SK, Kancir S, et al. Comparison of hepatitis C treatment patterns in patients with and without psychiatric and/or substance use disorders. J Viral Hepat 2006; 13(4): 235-41. [http://dx.doi.org/10.1111/j.1365-2893.2005.00681.x] [PMID: 16611189]

[17] Cawthorne CH, Rudat KR, Burton MS, et al. Limited success of HCV antiviral therapy in United States veterans. Am J Gastroenterol 2002; 97(1): $149-55$ [http://dx.doi.org/10.1111/j.1572-0241.2002.05439.x] [PMID: 11808940]

[18] Edlin BR, Kresina TF, Raymond DB, et al. Overcoming barriers to prevention, care, and treatment of hepatitis C in illicit drug users. Clin Infect Dis 2005; 40(Suppl. 5): S276-85. [http://dx.doi.org/10.1086/427441] [PMID: 15768335]

[19] Scheft H, Fontenette DC. Psychiatric barriers to readiness for treatment for hepatitis C Virus (HCV) infection among injection drug users: clinical experience of an addiction psychiatrist in the HIV-HCV coinfection clinic of a public health hospital. Clin Infect Dis 2005; 40(Suppl. 5): S292-6.

[http://dx.doi.org/10.1086/427443] [PMID: 15768337] 
[20] Morrill JA, Shrestha M, Grant RW. Barriers to the treatment of hepatitis C. Patient, provider, and system factors. J Gen Intern Med 2005; 20(8): 754-8

[http://dx.doi.org/10.1111/j.1525-1497.2005.0161.x] [PMID: 16050887]

[21] Huckans MS, Loftis JM, Blackwell AD, Linke A, Hauser P. Interferon alpha therapy for hepatitis C: treatment completion and response rates among patients with substance use disorders. Subst Abuse Treat Prev Policy 2007; 2(4): 4. [http://dx.doi.org/10.1186/1747-597X-2-4] [PMID: 17222348]

[22] Hauser P, Morasco BJ, Linke A, et al. Antiviral completion rates and sustained viral response in hepatitis C patients with and without preexisting major depressive disorder. Psychosomatics 2009; 50(5): 500-5.

[http://dx.doi.org/10.1016/S0033-3182(09)70843-6] [PMID: 19855036]

[23] Loftis JM, Hauser P. The phenomenology and treatment of interferon-induced depression. J Affect Disord 2004; 82(2): 175-90. [http://dx.doi.org/10.1016/j.jad.2004.04.002] [PMID: 15488246]

[24] Hauser P, Loftis JM, Dieperink E, Garcia-Tsao G, Rigsby M, Willenbring M and the Veteran Health Administration Hepatitis C Resource Center Program. Depression and substance use disorders in chronic hepatitis C: Implications of new guidelines and experience in the VA health care system. Fed Pract 2004; 21(7): 90-102.

[25] Sylvestre DL, Loftis JM, Hauser P, et al. Co-occurring Hepatitis C, substance use, and psychiatric illness: treatment issues and developing integrated models of care. J Urban Health 2004; 81(4): 719-34. [http://dx.doi.org/10.1093/jurban/jth153] [PMID: 15466851]

[26] Huckans MS, Blackwell AD, Harms TA, Indest DW, Hauser P. Integrated HCV treatment: Addressing comorbid substance use disorders, psychiatric disorders, and HIV infection. AIDS 2005; 19(3): S106-15.

[http://dx.doi.org/10.1097/01.aids.0000192078.49185.b0] [PMID: 16251805]

[27] Loftis JM, Hauser P. Treating hepatitis C in patients with comorbid psychiatric and substance use disorders. Dir Psychiatry 2008; 28(4): 227-43.

[28] Loftis JM, Hauser P. Pain and opioid use in chronic liver disease: optimal treatment must address the mental health care needs of the patient. Dig Dis Sci 2013; 58(10): 2753-5.

[http://dx.doi.org/10.1007/s10620-013-2809-4] [PMID: 23959213]

[29] Hauser P, Kern S. Psychiatric and substance use disorders co-morbidities and hepatitis C: Diagnostic and treatment implications. World J Hepatol 2015; 7(15): 1921-35. [http://dx.doi.org/10.4254/wjh.v7.i15.1921] [PMID: 26244067]

Peter Hauser

Division of Mental Health

Long Beach VA Medical Center

United States

Tel: +1-562-826-8000; ext 2629

Fax: +1-562-826-2221

Email: peter.hauser2@va.gov

(C) Peter Hauser; Licensee Bentham Open.

This is an open access article licensed under the terms of the Creative Commons Attribution-Non-Commercial 4.0 International Public License (CC BY-NC 4.0) (https://creativecommons.org/licenses/by-nc/4.0/legalcode), which permits unrestricted, non-commercial use, distribution and reproduction in any medium, provided the work is properly cited. 